\title{
Cronkhite-Canada-szindróma
}

\author{
Nagy Anita dr. ${ }^{1}$ - Tóth Levente dr. ${ }^{1}$ - Theisz János dr. ${ }^{1}$ \\ Bajkó Nándor dr. ${ }^{2}$ - Zolnai Zsófia dr. ${ }^{3}$ - Varga Mária ${ }^{4}$ - Igaz Iván dr. ${ }^{1,5}$
}

\author{
${ }^{1}$ Szent Imre Egyetemi Oktatókórház, Gasztroenterológia Profil, Budapest \\ ${ }^{2}$ Szent Imre Egyetemi Oktatókórház, Képalkotó Diagnosztikai Osztály, Budapest \\ ${ }^{3}$ Szent Imre Egyetemi Oktatókórház, Patológiai Osztály, Budapest \\ ${ }^{4}$ Szent Imre Egyetemi Oktatókórház, Dietetikai Szolgálat, Budapest \\ ${ }^{5}$ Szent Margit Kórház, Gasztroenterológia Osztály, Budapest
}

\begin{abstract}
A Cronkhite-Canada-szindróma egy extrém ritka, nem öröklődő, gyomor-bél rendszeri polyposissal, fehérjevesztő enteropathiával és ectodermalis elváltozásokkal járó megbetegedés. A világon eddig összesen körülbelül 500 esetet jegyeztek fel. Az etiológia pontosan nem tisztázott, hátterében elsősorban autoimmun folyamatot feltételeznek. A diagnózis a páciens kórtörténetén, a fizikális vizsgálaton, az endoszkópos képen és a szövettani leleten alapul. A jelen közleményben egy 71 éves férfi beteg esetét mutatjuk be. A klinikai kép és az elvégzett vizsgálatok alapján a tünetek hátterében Cronkhite-Canada-szindrómát igazoltunk, majd a szakirodalomban leggyakrabban alkalmazott kombinált protonpumpagátló, kortikoszteroid és meszalazin adását vezettük be, illetve táplálásterápiát alkalmaztunk. Tudomásunk szerint Cronkhite-Canada-szindrómás beteg esete Magyarországon elsőként kerül ismertetésre. Orv Hetil. 2021; 162(11): 432-438.
\end{abstract}

Kulcsszavak: Cronkhite-Canada-szindróma, polyposisszindróma, fehérjevesztő enteropathia, onychodystrophia

\section{Cronkhite-Canada syndrome}

Cronkhite-Canada syndrome is an extremely rare, noninherited disease, characterized by gastrointestinal polyposis, protein-losing enteropathy and ectodermal abnormalities. Approximately 500 cases have been reported worldwide. The aetiology is unknown, most probably autoimmune mechanisms may be involved. The diagnosis is based on patient history, physical examination, endoscopic findings and histology. Here we report the case of a 71-year-old male, diagnosed with Cronkhite-Canada syndrome. The treatment consisted of proton-pump inhibitor, corticosteroids, mesalazin and nutritional therapy. To the best of our knowledge, this is the first report of Cronkhite-Canada syndrome in Hungary.

Keywords: Cronkhite-Canada syndrome, gastrointestinal polyposis, protein-losing enteropathy, onychodystrophy

Nagy A, Tóth L, Theisz J, Bajkó N, Zolnai Zs, Varga M, Igaz I. [Cronkhite-Canada syndrome]. Orv Hetil. 2021; 162(11): 432-438.

(Beérkezett: 2020. szeptember 13.; elfogadva: 2020. szeptember 29.)

\section{Rövidítések}

ANA = antinukleáris antitest; $\mathrm{BMI}=($ body mass index $)$ testtömegindex; CCS = Cronkhite-Canada-szindróma; CMV $=$ cytomegalovirus; CRP $=$ C-reaktív protein; $\mathrm{CT}=($ computed tomography) számítógépes tomográfia; EBV = Epstein-Barr-vírus; $\mathrm{HIV}=$ humán immundeficienta-virus; IgG = immunglobulin$\mathrm{G} ; \mathrm{IgM}=$ immunglobulin- $\mathrm{M} ; \mathrm{MR}=$ mágneses rezonancia; PPI $=$ protonpumpa-inhibitor; $\mathrm{TNF}=$ tumornekrózis-faktor

A Cronkhite-Canada-szindróma (CCS) gyomor-bél rendszeri panaszokkal, gastrointestinalis polyposissal és ectodermalis elváltozásokkal járó sporadikus, nem öröklődő megbetegedés [1]. Extrém ritka, incidenciája
1/1 000 000. Napjainkig az egész világon körülbelül 500 esetet jegyeztek fel [2]. Mortalitása magas, az 5 éves halálozási arány kb. 55\% [3]. Az etiológia ismeretlen, elsősorban autoimmun hátteret feltételeznek. A diagnózis felállítása a klinikum, az endoszkópos kép és a szövettani lelet alapján történik. Ritka előfordulása miatt általánosan elfogadott kezelési protokoll nem ismert. A szakirodalom alapján a leggyakrabban táplálásterápiát alkalmaznak kortikoszteroiddal, protonpumpa-inhibitorral (PPI) vagy $\mathrm{H}_{2}$-receptor-blokkolóval kiegészítve. Bizonyos esetekben sikert értek el meszalazin, szulfaszalazin, azatioprin, ciklosporin, tumornekrózis-faktor (TNF) elleni antitestekkel és Helicobacter-pozitivitás esetén a H. pylori 
eradikációjával is [4-6]. Sebészeti beavatkozás (bélreszekció) elsősorban szövődményes esetekben jön szóba [7]. Szigorú endoszkópos utánkövetés az esetek 13\%ában kialakuló gyomor-bél rendszeri daganatok miatt szükséges [8].

\section{Esetismertetés}

A 71 éves férfi betegünk kórelőzményében elsődleges magasvérnyomás-betegség, bal alsó végtagi thrombosis, papillaris húgyhólyagdaganat, krónikus pitvarfibrilláció miatti kezelés szerepel. Ez utóbbi miatt tartós antikoaguláns-terápiát vezettek be, acenokumarol formájában. Az alkoholfogyasztást és a dohányzást negálta.

Panaszai a diagnózis felállítását megelőzően 8 hónappal kezdődtek. Az első tünetek között ízérzészavar lépett fel, majd állandó szájszárazság, gyengeség, étvágytalanság alakult ki. Testsúlya fél év alatt $13 \mathrm{~kg}$-ot csökkent. Diffúz hasi fájdalom, gyakori, laza székürítés jelentkezett. Háziorvosa ex juvantibus metronidazolterápiát indított 10 napig $(3 \times 500 \mathrm{mg})$, ennek folytán a beteg hasi panaszai átmenetileg javultak. Kéz-, majd lábkörmei is sárgásan elszíneződtek, berepedeztek, végül pedig leváltak. Időszakosan hajhullást észlelt.

A hasi panaszok és a fogyás miatt ambuláns felső endoszkópia történt, melynek során gastroduodenitis és pangásos gastropathia került leírásra. Az antrumból vett biopszia kifejezett aktivitást mutató, idült gastritist igazolt, H. pylori pozitivitással. Eradikációs terápiában részesült (10 napig amoxicillin, levofloxacin, bizmut és ezomeprazol), majd tartós PPI-terápiát vezettünk be. A panaszok kezdete után kb. fél évvel állapota nem javult, új tünetként vérszékelés lépett fel, ezért fekvőbeteg-osztályos kivizsgálás mellett döntöttünk. Fizikális statusából a cachexia, az ajkak és a tenyér hyperpigmentatiója, a hyperaemiás nyelv, az enyhe alopecia, illetve a kéz- és lábkörmökön lévő onychodystrophia érdemel említést (1. ábra).

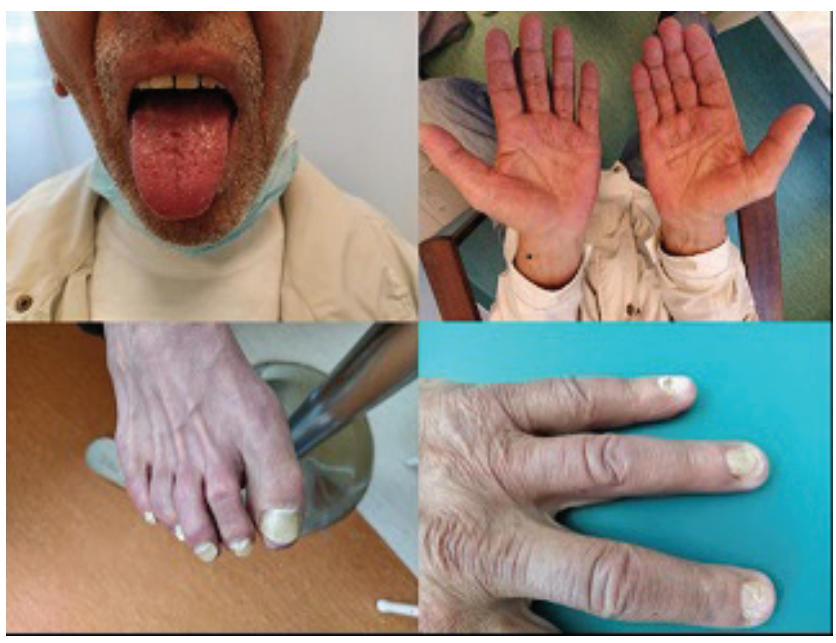

1. ábra

Ectodermalis elváltozások: az ajkak és a tenyér hyperpigmentatiója, a kéz- és lábkörmök elszíneződése, leválása
A laboratóriumi értékek közül a következők voltak kiemelhetók: csökkent összfehérje: 50,7 (ref.: 66-87), albumin: 33,1 (ref.: 35-50), globulin: 18 (ref.: 25-30), enyhén emelkedett CRP: 18,2 (ref.: 0,0-5), emelkedett szérumvas: 42,7 (ref.: 9-30), transzferrinszaturáció: 94,41 (ref.: 16-45), csökkent transzferrinszint: 1,8 (ref.: $2,2-3,6)$.

Egyebekben a vérkép, az ionstatus, a májenzimek és a vesefunkció eltérés nélküli volt, normális $\mathrm{B}_{12^{-}}$, folsavszint, negatív coeliakiapanel igazolódott, a pajzsmirigyhormonok is a normáltartományban voltak. A CMV-, EBV-szerológiai vizsgálat korábban lezajlott CMV-fertőzést igazolt. Az immunglobulinok közül az IgG- és az IgM-szint jelzetten csökkent, a béta-2-mikroglobulin szintje enyhén emelkedett, a HIV-szerológia negatív, az autoimmun panel eltérés nélküli volt.

A beteg BMI-je ekkor $20,7 \mathrm{~kg} / \mathrm{m}^{2}$ volt, ami a normálérték alsó határának felel meg.

A jelentős fogyás és a hasi panaszok miatt kontrasztanyagos hasi-kismedencei CT-vizsgálat készült, melyen malignitásra utaló eltérés nem volt látható; a vastagbél mentén néhány diverticulum ábrázolódott. A kolonoszkópia során a rectum distalis $10 \mathrm{~cm}$-ét leszámítva a vastagbél teljes hosszában számtalan, kisebb-nagyobb hyperaemiás polyp volt megfigyelhető (2.ábra). A coecumban

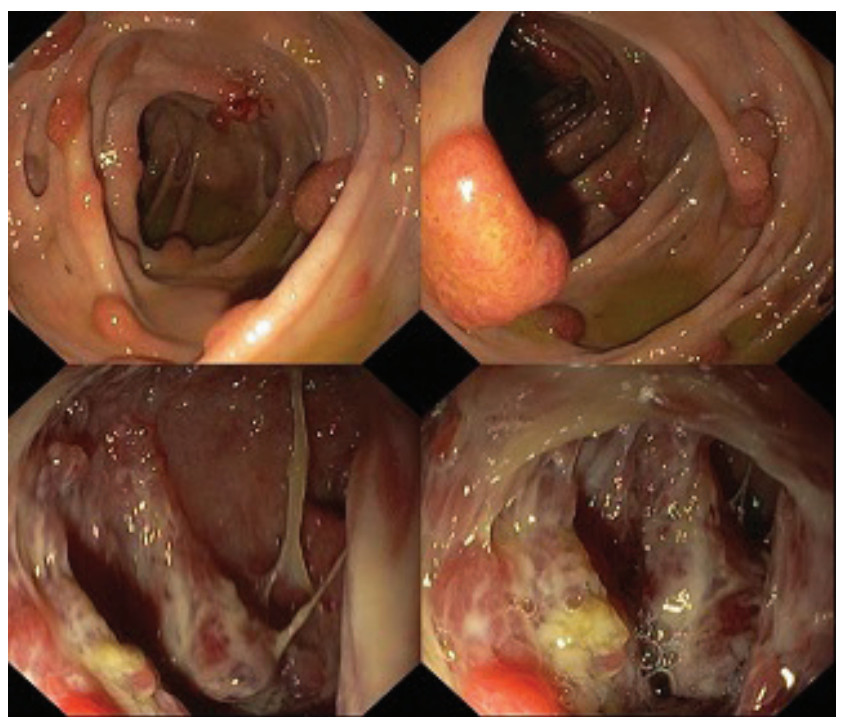

2. ábra | A vastagbélben látható polypoid képletek a kolonoszkópia során

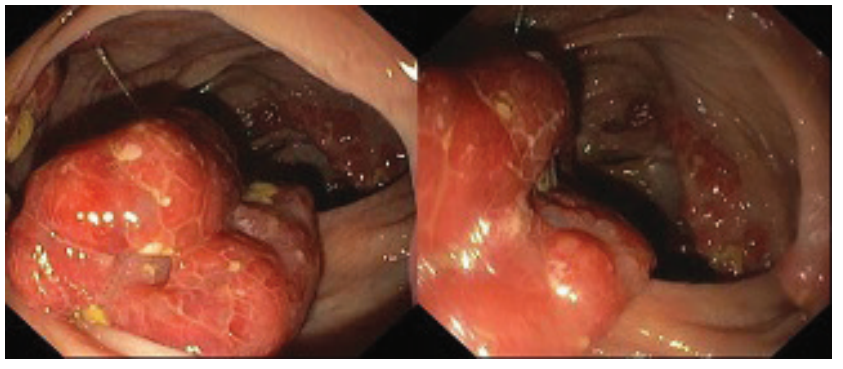

3. ábra | Coecumpolyp endoszkópos képe 
egy nagyobb, körülbelül $3 \mathrm{~cm}$-es polyp ábrázolódott, környezetében több kisebb polypussal (3. ábra). A coecumban és a sigmabélben észlelt nagyobb polypokból biopsziát végeztünk, melyek a szövettani leletezés alapján gyulladásos polypnak és pseudopolypnak feleltek meg. Az egyik esetben a stromában, a másik mintánál pedig a lamina propriában oedemát, vegyes lobsejtes beszúrôdést azonosítottak; dysplasia jelei nem voltak megfigyelhetők (4. és 5. ábra). A vékonybélstatus felmérésére MR-enterográfiás vizsgálatot szerveztünk. A gyomornyálkahártya teljes egészében hypertrophiás megjelenésú volt, ép külső kontúr mellett (6. ábra). A perigastricus zsírszövet megkíméltnek mutatkozott. A felvétel készítésekor a jejunum oralis fele üres volt. Az ileum a terminális és a preterminális szakaszon, körülbelül $20 \mathrm{~cm}$ hoszszan körkörös fali megvastagodást mutatott, a környező zsírszövet itt is békés volt (7. ábra). A colon teljes hoszszában számos kis, kontrasztanyagot halmozó, polypoid, 2-10 mm átmérőjü, intraluminalis struktúra volt azonosítható (8. ábra).

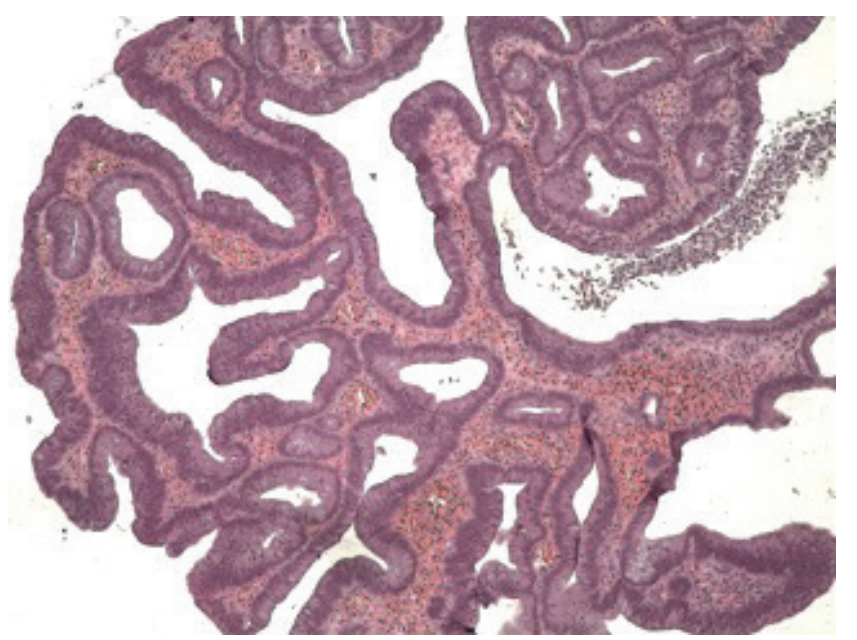

4. ábra

$$
\mid \begin{aligned}
& \text { Adenoma tubulovillosum a coecumban, enyhe fokú dysplasiával } \\
& \text { (szövettani lelet, hematoxilin-eozin festés) }
\end{aligned}
$$

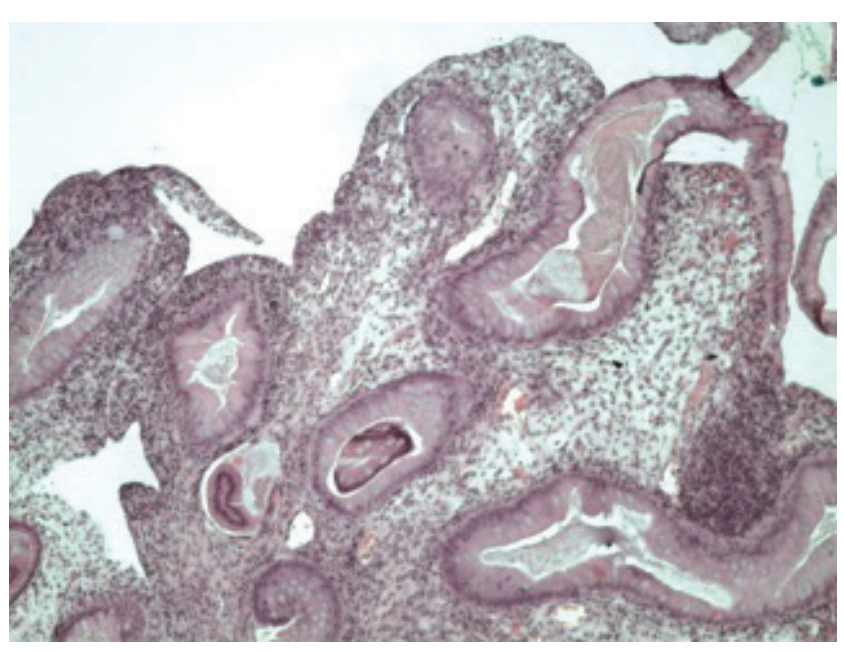

5. ábra

Gyulladásos pseudopolyp a coecumban (szövettani lelet, hematoxilin-eozin festés)

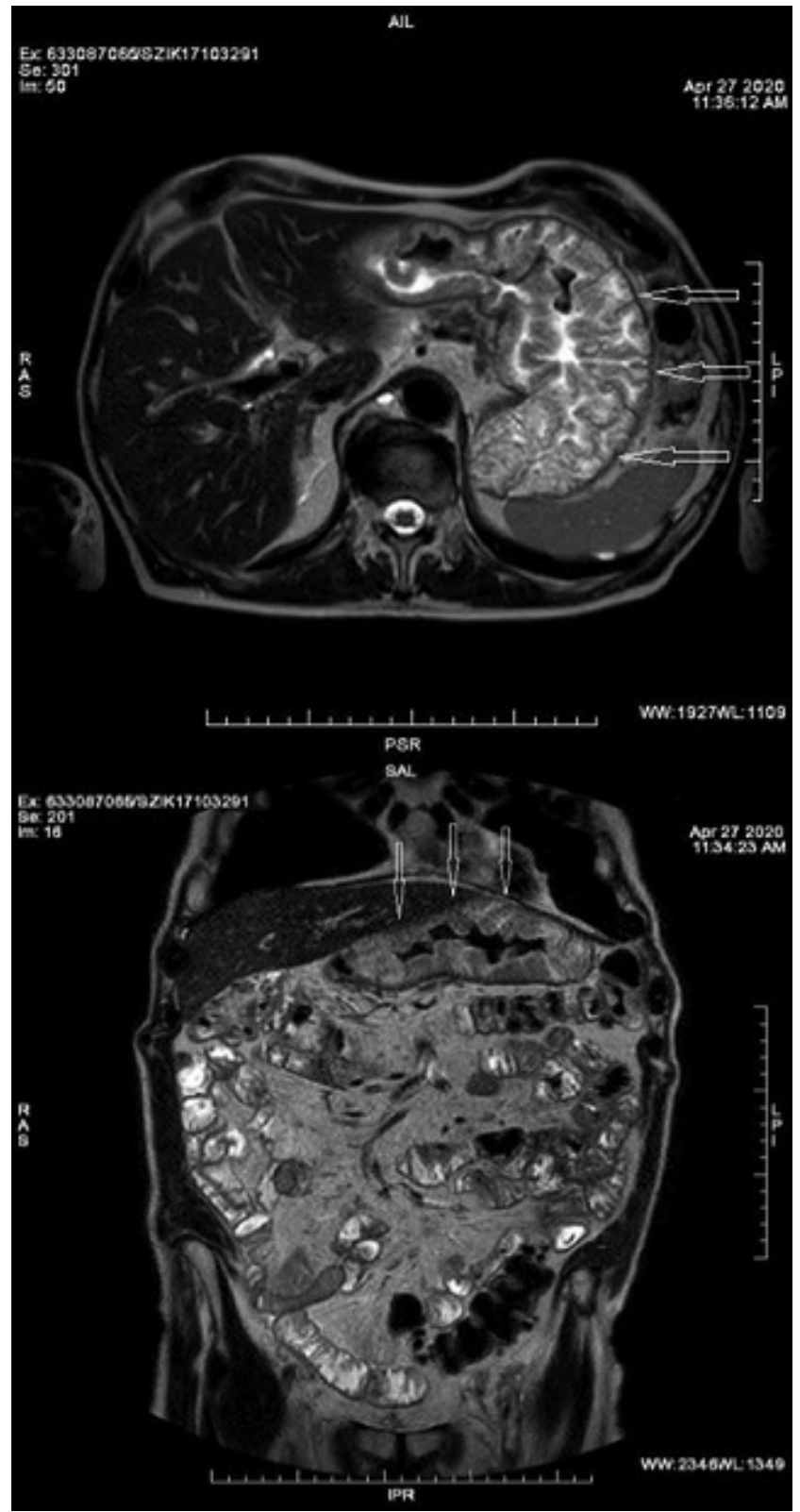

6. ábra $\mid \begin{aligned} & \text { MR-vizsgálaton a gyomor nyálkahártyája teljes egészében } \\ & \text { hypertrophiás. Felső panel haránt, alsó panel frontalis metszet } \\ & \mathrm{MR} \text { = mágneses magrezonancia }\end{aligned}$

Az összes lelet ismeretében a nagyon ritka előfordulású CCS lehetősége merült fel. A diagnózis megerósítésére kiegészítő vizsgálatokat terveztünk, melyeket az új típusú koronavírus okozta járványra való tekintettel betegünk ideiglenesen visszautasított. A járványügyi veszélyhelyzet lezajlását követően kivizsgálását folytattuk. A széklettenyésztés során Salmonella-, Shigella-, Yersinia-, Campylobacter-és Clostridium-fertőzés nem igazolódott. Az ismételt gasztroszkópia során a korábbival teljes mértékben megegyező képet láttunk (9.ábra). Az antrumból és a duodenumból többszöri mintavétel történt. Az antrumban egy hyperplasticus polyp, illetve idült lobsejtes beszû́rődés igazolódott. A korábbi sikeres eradikációt követően a szövettani mintában $H$. pylori 


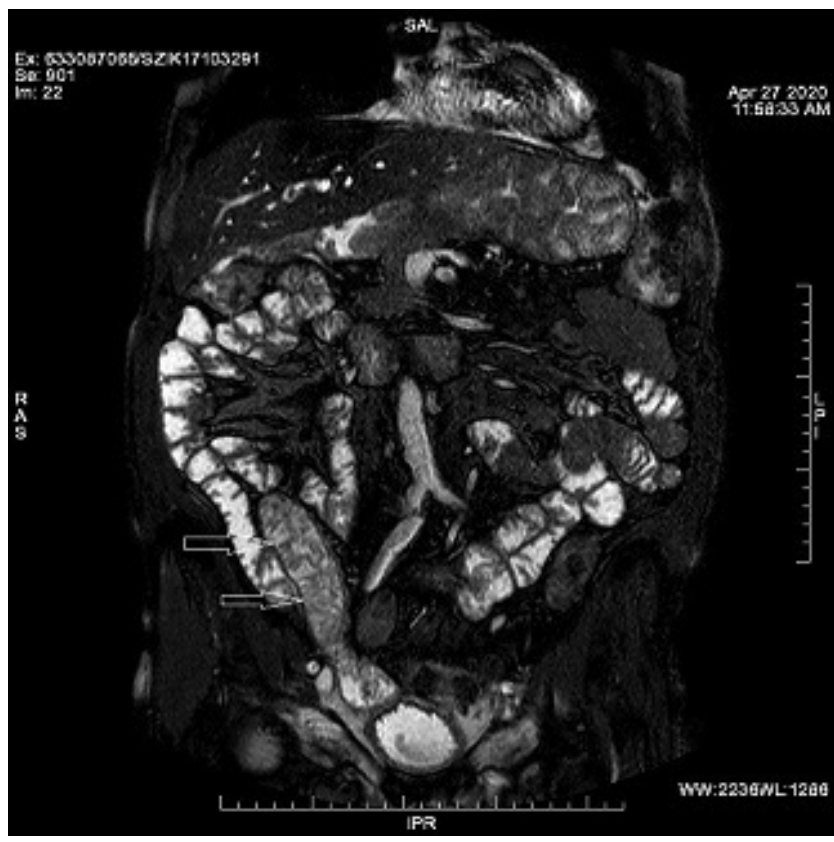

\begin{tabular}{l|l} 
7. ábra & Hasi MR-kép, frontalis metszet: a terminalis ileum körkörös fali
\end{tabular} megvastagodást mutat (nyilak)

$\mathrm{MR}=$ mágneses magrezonancia

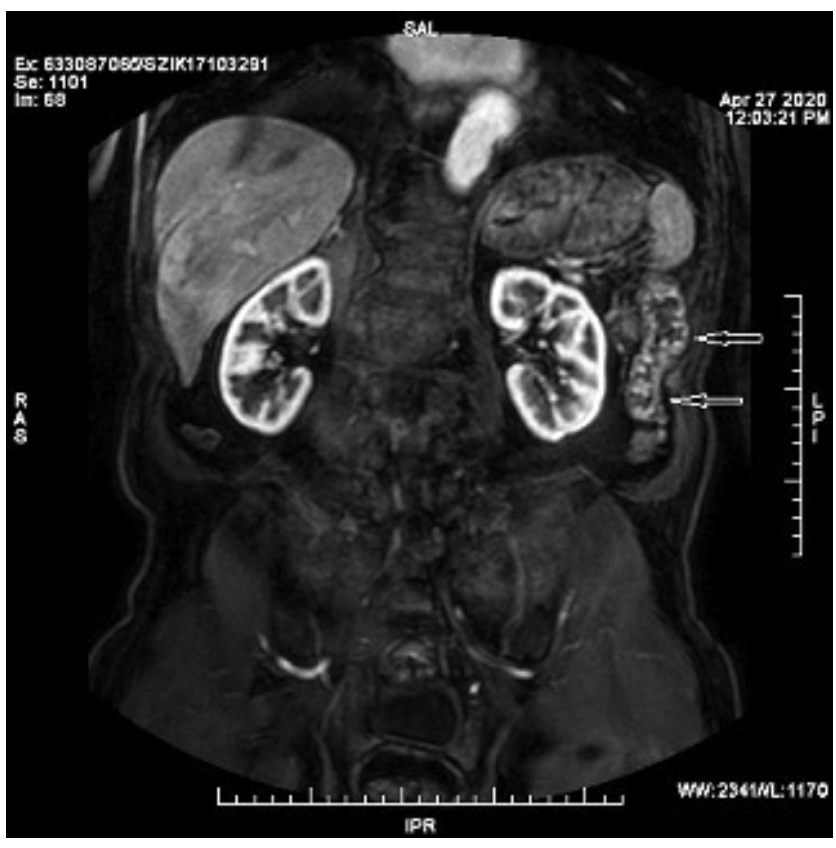

8. ábra

$$
\begin{aligned}
& \text { Hasi MR-kép, frontalis metszet: a colon descendens szakaszán } \\
& \text { számos kis, kontrasztanyagot halmozó polypoid, intraluminalis } \\
& \text { struktúra azonosítható (nyilak) } \\
& \text { MR = mágneses magrezonancia }
\end{aligned}
$$

már nem volt látható. A nyombélból vett minta aspecifikus duodenitist mutatott pseudopolypus-megjelenéssel (10. ábra). Az ileumintubáció és a többszörös biopsziás mintavételek céljából ismételt kolonoszkópia során szintén a korábbival megegyező eltéréseket észleltünk. A terminális ileumban is számtalan hyperaemiás polyp és fella-

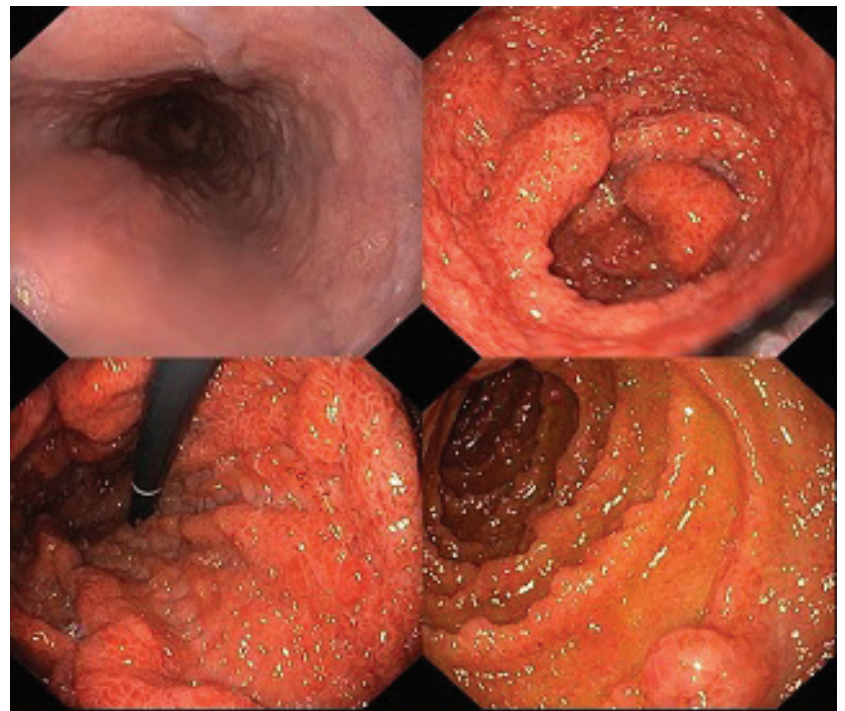

9. ábra A nyelőcső ép. A gyomor nyálkahártyája erythemás, gyulladt, pangásos jellegú. A duodenumban számos apró polypus látható (endoszkópos kép)

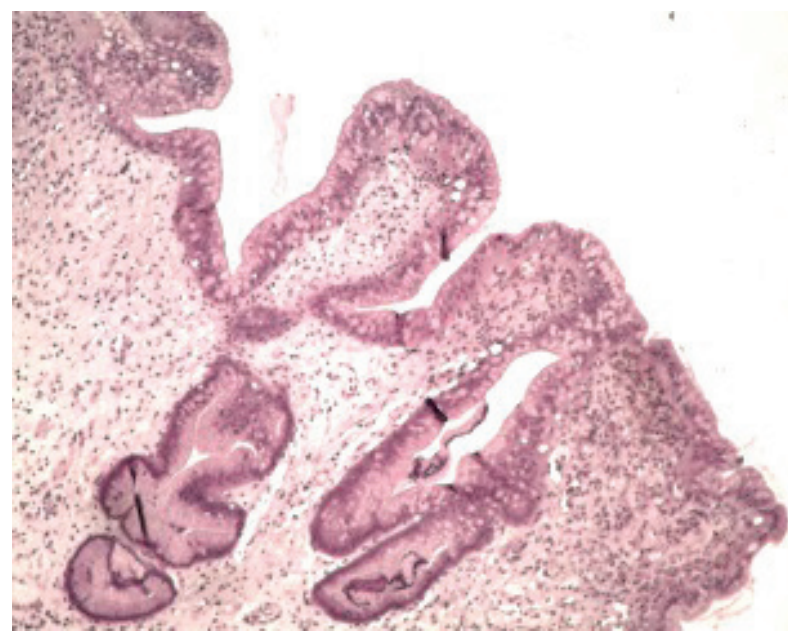

10. ábra

Polypoid alakzatú gyomorantrum-nyálkahártyarészlet. A miri gyek megnyúltak, a lamina propriában oedema és enyhe fokú idült, lobsejtes beszúrődés látható (szövettani lelet, hematoxilin-eozin festés)

zult nyálkahártya ábrázolódott. Az ileumból vett minta kórszövettani feldolgozása során a felszín több helyen kifekélyesedett volt, a lamina propria lobos, karéjozott magvú granulocytákat tartalmazott, de dysplasiára utaló jelek nem voltak észlelhetők (11. ábra). A vastagbélből elektrokoagulációval két, 1 cm-es polypot távolítottunk el. Az egyik esetben hyperplasticus polyp, a másik mintánál enyhe fokú dysplasiát mutató adenoma tubulovillosum igazolódott. A teljes vékonybél-érintettség feltérképezésére kapszula-endoszkópiát végeztünk. A felvételen a vékonybél vizsgált szakaszán végig foltosan hyperaemiás nyálkahártya volt látható, kifejezetten vaskos, oedemás boholyzattal, mely helyenként polypoid megjelenést mutatott, de valódi polypot azonosítani nem tudtunk (12. ábra). 


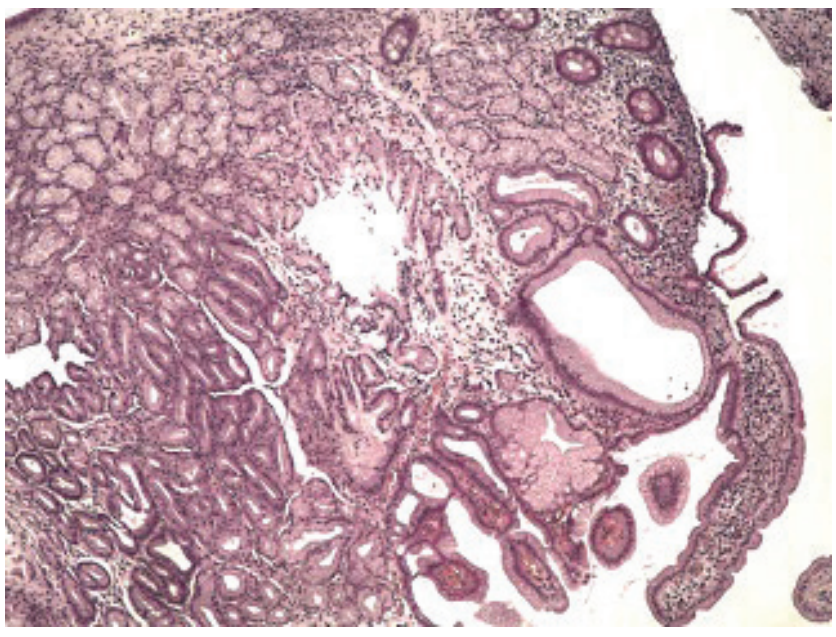

11. ábra

Töredezett vékonybél-nyálkahártya. A felszín több helyen kifekélyesedett, a lamina propria lobos, karéjozott magvú granulocytákat tartalmaz (szövettani lelet, hematoxilin-eozin festés)

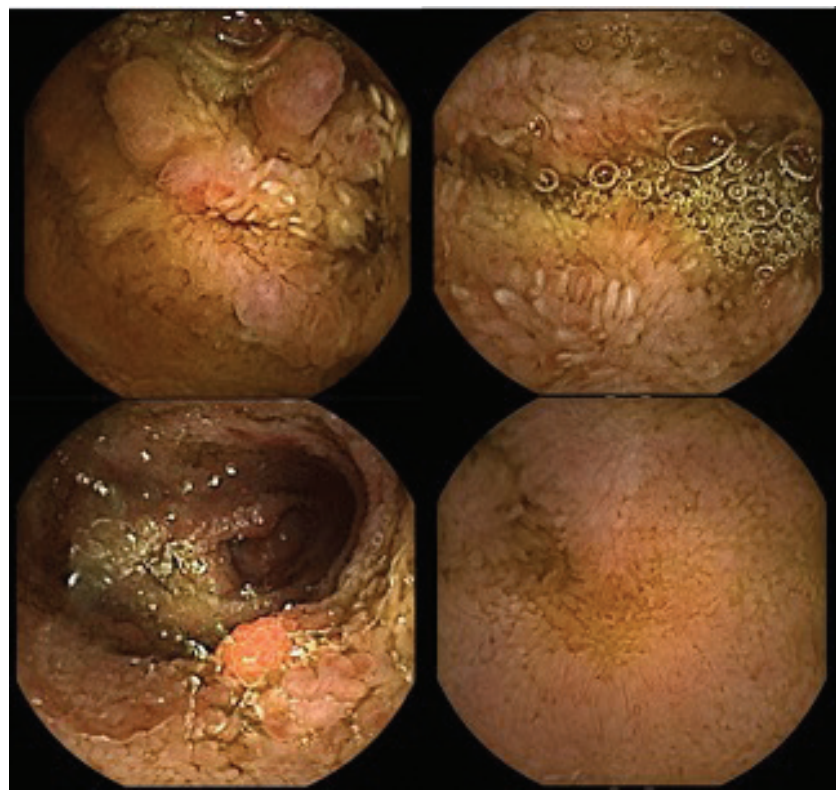

12. ábra

A vékonybél nyálkahártyája végig oedemás, hyperaemiás. A boholyzat oedemája néhol polypoid megjelenést okoz (kapszulaendoszkópia)

Betegünk kórelőzménye, fizikális vizsgálata, a képalkotó vizsgálatok, endoszkópos és szövettani leletei alapján együttesen felállítottuk a CCS diagnózisát.

Ideiglenesen, tápszeres kiegészítés mellett, szulfaszalazinterápiát állítottunk be, melyet páciensünk rosszul tolerált. Később meszalazinterápiát indítottunk. Egyértelmü terápiás javaslat hiányában, széles körü irodalomkutatást követően, $2 \times 40 \mathrm{mg}$ pantoprazol-, $3 \times 500 \mathrm{mg}$ meszalazin-, $1 \times 40 \mathrm{mg}$ metilprednizolon-terápiát állítottunk be, D-vitamin- és káliumpótlás mellett. Testöszszetétel-mérés és dietetikai konzultáció alapján colitises, fehérjében gazdag, roboráló étrend mellett napi $3 \times 4$ evőkanál glutaminpótlást és szemielementáris tápszeres kiegészítést javasoltunk, táplálkozási napló vezetésével.
A bevezetett terápia hatására betegünk testsúlya 3 hónap alatt $6 \mathrm{~kg}$-ot nótt, BMI-je 20,7 kg/m²-ról 22,7kg/m²re változott, székletszáma napi 1-2-re csökkent, a körömeltérések is javultak.

A későbbiekben rendszeres állapotfelmérést, laboratóriumi kontrollt és félévenkénti endoszkópos kontrollvizsgálatokat tervezünk.

\section{Megbeszélés}

A CCS egy igen ritkán előforduló polyposisszindróma. Az első esetet 1955-ben Leonard Wolsey Cronkhite és Wilma Jeanne Canada ismertette [2]. Azóta az egész világon körülbelül 500 eset került leírásra, ennek háromnegyede Japánban $[2,9]$. A CCS döntően az ötödik évtizedben jelentkezik, nemek közti megoszlása enyhe férfidominanciát mutat (3 : 2) [10]. Nem öröklődő megbetegedés, eddig összesen egy esetben fordult elö, hogy egy családon belül két személy is érintett volt [11].

Az etiológia jelenleg ismeretlen. A több páciensnél is kimutatott emelkedett szérum-ANA-szint, a polypok szövettani vizsgálata során észlelt IgG4-pozitivitás és a társbetegségként gyakran megjelenő szisztémás lupus erythematosus és rheumatoid arthritis miatt autoimmun eredetet valószínúsítenek $[3,7,12]$. Triggerfaktorként a stressz, az immunrendszer múködési zavara és a $H$. pylo$r i$ fertőzés szerepe is felmerült $[12,13]$.

Betegünknél a szérum-ANA a normáltartományon belül volt, nem volt ismert autoimmun betegsége, ugyanakkor a felső endoszkópia során $H$. pylori pozitivitás igazolódott. Az elsőként jelentkező ízérzészavart és hasmenést követően étvágytalanság, hányás, fogyás, gyengeség, hasi fájdalom lép fel, majd megjelennek az ectodermalis tünetek is, alopecia, onychodystrophia, a tenyér, a talp, a szájüreg és a nyak bőrének hyperpigmentatiója alakul ki. Az ectodermalis eltéréseket a betegség kései fázisában malabszorpció következményének tartják, de néhány esetben, mint betegünknél is, az ectodermalis elváltozások korábban jelentkeztek [11, 12, 14]. A laboratóriumi vizsgálatokban a leggyakrabban anaemia, enyhe gyulladásosparaméter-emelkedettség, összfehérje- és albuminhiány jellemző [15].

Az endoszkópos vizsgálatok során a nyelőcső általában megkímélt. A gyomorban és a vékonybélben hatalmas redők és hyperaemiás polypok fordulnak elő. A vastagbél területén számtalan sessilis, haragosvörös polypoid elváltozás figyelhető meg. Szövettanilag hamartomatosus, hyperplasticus és gyulladásos polypok is előfordulhatnak. Jellemző kórszövettani elváltozás a lobsejtes beszưrődés, a jelentős submucosus oedema döntően a lamina propria rétegében és a mucosában tágult mirigyek [11, 13, 16].

A diagnózis a jellegzetes panaszok, az endoszkópos kép és a szövettani lelet alapján állítható fel. A kórisme megállapítása az extrém ritka előfordulás, illetve az egyértelmú diagnosztikus algoritmus hiánya miatt általában sokat késik. Esetünkben is 8 hónap telt el a panaszok kezdetétől a definitív diagnózis felállításáig. A korai diag- 
nózis jelentőségét a magas, kb. 55\%-os 5 éves mortalitás adja. A leggyakrabban előforduló szövődmények a súlyos cachexia, a gastrointestinalis vérzés, a visszatérő fertőzések és a pangásos szívelégtelenség [13, 15]. Gyomor-bél rendszeri daganatok az esetek 10-20\%-ában alakulnak ki. 1980 és 2011 között Japánban összesen 383, CCS-szel diagnosztizált pácienst jegyeztek fel, közülük 40 esetben igazolódott gyomordaganat, és 51 betegnél alakult ki malignus vastagbéltumor a követés során [4]. Az utóbbi adatok az endoszkópos követés jelentôségére hívják fel a figyelmet. Ugyan a legtöbb ajánlás tartalmazza ezt, de ideális gyakorisága nincs meghatározva. Tekintettel arra, hogy esetünkben adenomatosus polypot is találtunk, a félévente végzett endoszkópos kivizsgálás elfogadható opció lehet.

Míg a „konvencionális” adenomatosus polypok esetében bizonyított az ún. adenoma-carcinoma szekvencia, addig CCS esetén a carcinoma kialakulásának fokozott kockázata valószínúleg csak részben magyarázható azzal, hogy a colonban adenomatosus polypok is jelen lehetnek, a pontos etiológia nem ismert. A benignus és malignus polypok hasonlósága miatt az $1 \mathrm{~cm}$-t meghaladó átmérőjü elváltozások eltávolítása javasolt [6].

Széleskörüen elfogadott terápiás protokoll jelenleg nem létezik. Az esetek 5-10\%-ában kezelés nélkül is spontán regressziót észleltek, de a terápiás lehetőségek fejlődésével a prognózis is javult $[4,17]$. A legtöbb ajánlásban közös a táplálásterápia, a kortikoszteroid és a PPI-k alkalmazása. A táplálásra konkrét ajánlás nincs, az elvesztett kalória, folyadék, ásványi anyag és vitaminok pótlása javasolt. Egyes közlemények alapján az enteralis útvonal preferálandó, amennyiben a felszívódás és a nagyfokú étvágytalanság a megfelelő mennyiségek pótlását lehetővé teszi. Ugyanakkor más szerzők a bél kímélése céljából teljes parenteralis táplálást ajánlanak $[6,11]$. Anabolikus szteroidok használata az egyes vizsgálatok során észlelt alacsony hatékonyság és gyakori mellékhatások miatt nem javasolt. A kortikoszteroidok alkalmazása a terápiás sikereknek köszönhetően széleskörúen elterjedt. A dózisra és a kezelés időtartamára egyértelmú ajánlás nincs, a leggyakrabban napi 20-60 mg prednizolont alkalmaznak. Egy japán vizsgálatban 22, kortikoszteroiddal kezelt páciensből 15-ben észleltek hosszú távú remissziót, további 5 betegnél átmeneti javulást tapasztaltak $[6,18]$. Más esetben a szteroidot hídterápiaként alkalmazták az azatioprin hatásának kifejlődéséig. Biológiai terápiaként a TNF-alfa-gátló infliximabbal is sikereket értek el [7]. A hízósejtek lehetséges patogenetikai szerepét alapul véve egyes terápiás ajánlásokban $\mathrm{H}_{2}$-receptor-blokkoló, antihisztamin és membránstabilizáló kromolin is szerepel [5]. Egy középkorú japán CCS-es betegnél a javulást nem hozó szteroid-, antiplazmin- és táplálásterápiát a gyulladásos bélbetegségek során gyakran alkalmazott, $1500 \mathrm{mg} /$ nap dózisú meszalazinnal kiegészítve néhány nap elteltével tünetmentességet értek el, és fél éven belül a vastagbélben észlelt polypoid elváltozások is eltúntek [18]. CCS-ben gyakran észlelhe- tő $H$. pylori fertőzés, ezért több terápiás ajánlásban szerepel az antibiotikumkombinációkból és emelt dózisú PPI-terápiából álló eradikációs kezelés. Okamoto és társai egy 67 éves férfi betegnél klaritromicin, amoxicillin és lanzoprazol 14 napig alkalmazott kombinációjával 3 hónapon belül teljes panaszmentességet értek el, és 8 hónapon belül az ectodermalis elváltozások is megszüntek [19]. A szakirodalomban a számtalan gyógyszeres kombináció mellett a kezelés időtartamára vonatkozóan sincs egyértelmú ajánlás. A legtöbb esetben fél-egy éves kezelést alkalmaznak. Egy 210 esetet retrospektíven feldolgozó vizsgálat alapján a terápia megkezdését követően átlagosan 1,5-3 hónappal várható klinikai remisszió, míg az endoszkópos javuláshoz körülbelül 8 hónap szükséges [4].

A CCS extrém ritka és potenciálisan súlyos megbetegedés. A mortalitás a diagnózis felállításának késésével növekszik, ezért a korai diagnózis rendkívül fontos. A felismerést nagyban elősegíti, ha az endoszkópos szakemberek polyposisszindróma észlelése esetén tudatosan keresik az ectodermalis jegyeket.

Anyagi támogatás: A közlemény megírása, illetve a kapcsolódó kutatómunka anyagi támogatásban nem részesült.

Szerzői munkamegosztás: A cikk megírásában valamennyi szerző részt vett, és végleges változatát mindannyian elolvasták és jóváhagyták.

Érdekeltségek: A szerzőknek nincsenek érdekeltségeik.

\section{Irodalom}

[1] Sweetser S, Alexander GL, Boardman LA. A case of CronkhiteCanada syndrome presenting with adenomatous and inflammatory colon polyps. Nat Rev Gastroenterol Hepatol. 2010; 7 : $460-464$.

[2] Goto A. Cronkhite-Canada syndrome: epidemiological study of 110 cases reported in Japan. Nihon Geka Hokan 1995; 64: 3-14.

[3] Daniel ES, Ludwig SL, Lewin KJ, et al. The Cronkhite-Canada syndrome. An analysis of clinical and pathologic features and therapy in 55 patients. Medicine 1982; 61: 293-309.

[4] Watanabe C, Komoto S, Tomito K, et al. Endoscopic and clinical evaluation of treatment and prognosis of Cronkhite-Canada syndrome: a Japanese nationwide survey. J Gastroenterol. 2016; 51: 327-336.

[5] Ward EM, Wolfsen HC, Ng C. Medical management of Cronkhite-Canada syndrome. Southern Med J. 2002; 95: 272-274.

[6] Ward EM, Wolfsen HC. Pharmacological management of Cronkhite-Canada syndrome. Expert Opin Pharmacother. 2003; 4: 385-389

[7] Sweetser S, Ahlquist DA, Osborn NK, et al. Clinicopathologic features and treatment outcomes in Cronkhite-Canada syndrome: support for autoimmunity. Dig Dis Sci. 2012; 57: 496502 .

[8] Nagata K, Sato Y, Endo S, et al. CT endoscopy for the follow-up of Cronkhite-Canada syndrome. Int J Colorectal Dis. 2007; 22: 1131-1132. 
[9] Matsui S, Kibi M, Anami E, et al. A case of Cronkhite-Canada syndrome with multiple colon adenomas and early colon cancers. Nihon Shokakibyo Gakkai Zasshi 2011; 108: 778-786. [Japanese]

[10] Ward EM, Wolfsen HC. Review article: the non-inherited gastrointestinal polyposis syndromes. Aliment Pharmacol Ther. 2002; 16: 333-342.

[11] Kopácová M, Urban O, Cyrany J, et al. Cronkhite-Canada syndrome: review of the literature. Gastroenterol Res Pract. 2013; 2013: 856873

[12] Safari MT, Shahrokh S, Ebadi S, et al. Cronkhite-Canada syndrome: a case report and review of the literature. Gastroenterol Hepatol Bed Bench 2016; 9: 58-63.

[13] Yuan W, Tian L, Ai FY, et al. Cronkhite-Canada syndrome: a case report. Oncology Lett. 2018; 15: 8447-8453.

[14] Chakrabarti S. Cronkhite-Canada syndrome: a rare case report. J Clin Diagn Res. 2015; 9: OD08-OD09.

[15] Iqbal U, Chaudhary A, Karim AM, et al. Cronkhite-Canada syndrome: a rare case of chronic diarrhea. Gastroenterology Res. 2017; 10: 196-198.
[16] Jha AK, Kumar A, Singh SK, et al. Panendoscopic characterization of Cronkhite-Canada syndrome. Med J Armed Forces India 2018; 74: 196-200.

[17] Nakayama M, Muta H, Somada S, et al. Cronkhite-Canada syndrome associated with schizophrenia. Intern Med. 2007; 46: 175-180.

[18] Takakura M, Adachi H, Tsuchihashi N, et al. A case of Cronkhite-Canada syndrome markedly improved with mesalazine therapy. Dig Endosc. 2004; 16: 74-78.

[19] Okamoto K, Isomoto H, Shikuwa S, et al. A case of CronkhiteCanada syndrome: remission after treatment with anti-Helicobacter pylori regimen. Digestion 2008; 78: 82-87.

(Igaz Iván dr., Budapest, Tétényi út 12-16., 1115 e-mail: igaz.ivan@gmail.com

\section{"Brevis ipsa vita est sed malis fit longior." (Az élet ugyan rövid, de a bajok hosszúvá teszik.)}

A cikk a Creative Commons Attribution 4.0 International License (https://creativecommons.org/licenses/by/4.0/) feltételei szerint publikált Open Access közlemény, melynek szellemében a cikk bármilyen médiumban szabadon felhasználható, megosztható és újraközölhetö, feltéve, hogy az eredeti szerző és a közlés helye, illetve a CC License linkje és az esetlegesen végrehajtott módositások feltüntetésre kerülnek. (SID_1) 